\title{
Normal Reference Range
}

National Cancer Institute

\section{Source}

National Cancer Institute. Normal Reference Range. NCI Thesaurus. Code C78727.

Reported values within the typical or expected range. 